\title{
Transnational Somali Families in Cairo
}

\author{
Mulki Al-Sharmani
}

\begin{abstract}
In this article, I examine how diasporic Somalis in Cairo experience being part of transnational families. I analyze two practices through which transnational family relations are maintained, experienced, and negotiated: (1) living arrangements of relatives and management of family affairs and (2) the use of the Internet and videotapes. I argue that transnational families make collective decisions about which family members live together, where, and what their family obligations should be. However, although maintaining interdependent transnational families is crucial for the survival of family members, it has its tensions and challenges because of the competing interests and dreams of individual members. I examine these tensions and how they are negotiated by family members who live together in Cairo but share resources and family obligations with relatives living elsewhere. In short, this way of being and living in which individuals and families partake as they are physically separated in different nation-states has its uneven consequences and challenges for different Somalis depending on their legal statuses, education, gender, and identity claims.
\end{abstract}

\section{Résumé}

Dans cet article, j'examine la façon dont les membres de la diaspora somalienne du Caire vivent l'expérience de leur appartenance à des familles transnationales. J'analyse deux pratiques par lesquelles les relations familiales transnationales sont maintenues, vécues et gérées: (1) les conditions de logement des parents proches et l'administration des affaires familiales; et (2) l'utilisation de l'Internet et des vidéocassettes. Je soutiens que les familles transnationales prennent des décisions collectives quant aux membres de la famille qui doivent vivre ensemble, le lieu ou ils doivent vivre et ce que doivent êtres leurs obligations familiales. Cependant, malgré le fait que le maintien de familles transnationales interdépendantes soit crucial pour la survie des membres de ces familles, cela comporte des tensions et des défis à cause des intérêts divergents et des aspirations individuelles de chaque membre. J'examine ces tensions et la manière dont ils sont gérés par les membres de la famille vivant ensemble au Caire, mais partageant des ressources et des obligations familiales avec des proches parents vivant ailleurs. En bref, cette façon d'être et de vivre où les individus et les familles vivent en partage, tout en étant physiquement séparés et éparpillés dans différents états nations, a des conséquences et présente des défis qui sont différents pour chaque Somalien selon son statut juridique, son niveau d'éducation, son genre et ses revendications identitaires.

\section{Introduction}

W ith the advent of the civil war in 1991 and the collapse of the Somali state, a large number of refugees fled to Cairo from the homeland as well as from neighbouring Gulf countries. Most of those refugees and their families resettled in North America, Europe, and Australia by the mid-nineties. Since the late nineties, Cairo has attracted again a diverse group of Somali refugees from neighbouring countries such as Libya, Saudi Arabia, and Yemen as well refugees from Kenya and Somalia. Refugees who arrived from other host societies fled the homeland either in the late eighties or in the early nineties with the collapse of the state. Currently, the number of these refugees is 3,609 including recognized refugees and asylum seekers. ${ }^{1}$ The main reasons that were given by the refugees who left other Middle Eastern countries to come to Cairo were lack of a legal residence status, fears of deportation, and experiences of harassment and racism in daily encounters with government officials, employers, and other members of host societies. Moreover, many of these refugees were attracted to Cairo because of a shared perception that the office in the city of the United Nations High Commissioner of Refugees (UNHCR) resettled many Somalis in Western countries.

The reasons that many Somali refugees pursue resettlement in the West can be partially explained by the dreams

(C) Mulki Al-Sharmani, 2007. This open-access work is licensed under a Creative Commons Attribution-NonCommercial 4.0 International License, which permits use, reproduction and distribution in any medium for non-commercial purposes, provided the original author(s) are credited and the original publication in Refuge: Canada's Journal on Refugees is cited. 
of legal citizenship, employment, and a better standard of living-something that many migrants to Western countries aspire to. But seeking resettlement in the West for Somali refugees can be better understood if we also examine how these refugees are an integral part of a network of transnational interlinked families and communities whose members pool resources, debate, and make collective decisions about the future of different members living in different nation-states. Refugees in Cairo depend on their transnational families and communities for livelihood and securing a better future for themselves and their relatives. They invest in this transnational support system by sharing a variety of resources (e.g., money, housing, information about different host societies, and family obligations such as taking care of children, elderly relatives, or invalid family members).

The advantages and the limitations of what resettlement in the West has to offer are ever more real for the refugees in Cairo as they share the city with an increasing number of Somali families who are citizens of Western countries and who have moved to Egypt since the late nineties. Although there is no official number of this latter group of Somali émigrés, my count, which is based on tallying individual families between 2001 and 2003, indicates that the number is a little over two hundred families. Refugees aspire to the benefits of the status of this higher class of diasporic Somalis who are holders of Western passports that ensure them mobility and eligibility for residence in different nation-states. On the one hand, refugees desire the advantages of Western citizenship as they observe Somali Americans or Europeans obtain and renew residence in Cairo as Western nationals and rent or buy apartments in new middle-class neighbourhoods with the economic assets that they acquired from employment in the West and running small trading businesses in the Middle East. On the other hand, the limitations of Western citizenship, which have not helped Somalis in Western countries escape the lives of racialized and economically marginalized immigrants, are stories that are recounted again and again to refugees by their fellow Somalis who moved from the West. $^{2}$

\section{Transnational Families: Family Support and Tensions}

Almost all Somalis in Cairo are part of families whose members live in different nation-states, but who are interdependent for their livelihood and well-being. In addition to sending and receiving remittance money to and from one another, family members are involved in each other's lives in significant ways. For example, the living arrangements of most refugee and émigré families demonstrate a mechanism through which family members in Cairo and elsewhere are interconnected through ties of obligations and expectations. By making collective decisions about who lives with whom and where, relatives across nation-states share the burdens of securing livelihood, the rearing of children and younger siblings, and providing care for the elderly and the invalid in the family. Yet these transnational practices of maintaining families create tensions between different family members who have to negotiate their individual needs and aspirations as well as what they deem to be in the best interest of the family. In what follows, I will present ethnographic examples of practices of maintaining transnational families and their inherent tensions.

Nuriya is a thirty-year-old unmarried refugee woman who moved to Cairo from Somalia four years ago. Since her arrival, she has been living with her aunt and cousins. Her aunt is an émigré who has recently moved from Canada with her three small children, while her husband and an older daughter live and work in Toronto. Before Nuriya's arrival in Cairo, her parents made arrangements with her aunt to provide a home for Nuriya during her stay in Cairo to pursue refugee status and resettlement possibilities in the West. Her aunt agreed. In fact, she considers her taking care of Nuriya as her familial obligation. She is also grateful that her brother, Nuriya's father, has been taking care of their elderly mother and younger siblings in Somalia. Nuriya's aunt relies on her to do the housework and child care, especially during her frequent trips to North America and other Middle Eastern countries. Nuriya does not get paid for the housework and childcare, which both she and her aunt perceive as the familial duty of a younger dependent relative towards her older relative and guardian. However, Nuriya receives from her aunt a monthly allowance of 50 Egyptian pounds (LE) for her personal expenses (e.g., Internet costs, transportation fare, etc.). Her aunt also pays for her weekly Arabic and English classes, which cost LE 40 a month.

While Nuriya, her aunt, and their family members in Somalia and in the West depend on one another for their livelihood and well-being, there are tensions that are felt by some family members who feel that they are giving a lot more than others and who resent that their individual needs and aspirations are being sacrificed because of their obligations towards their transnational families. Nuriya voices such feelings. She appreciates that her aunt supports her and even helps her pursue some education, but she feels that her aunt benefits a great deal more from the free long hours of housekeeping and child-care services which Nuriya provides for her family. Moreover, since she has been rejected by the UNHCR for resettlement in the West, Nuriya has been unsuccessfully soliciting support from her 
aunt and other family members in the West and Gulf countries to finance the costs of her being smuggled to Europe. Her aunt refuses to contribute to her travel costs, and argues that it is a risky endeavour and is not the right time because there are a lot of family in Somalia who need her financial support. Nuriya's parents as well as two other aunts who live in Dubai are also not supportive of funding Nuriya's travel to the West. Nuriya, however, argues that her being trapped in Egypt with no future is detrimental not only to her future but also to that of her family. If she resettles in the West, she argues that she will be able to work and remit money to the family.

Nuriya also complains that because most of her time is spent in caring for her aunt's family she is unable to work as a domestic worker, which would help her save money. She has looked into the possibility of moving out of her aunt's place and sharing an apartment with three female friends who work as domestic workers. Nonetheless, Nuriya is fearful of angering her aunt and the rest of the family. She is not sure either how much she can save even if she finds work as a domestic worker since she will be expected then to remit some of her income to her family in Somalia. She is also concerned about the stigma attached to the job of a domestic worker. She says that, although living with her aunt is not helpful to her in the long term, at least she perceives herself and is perceived by others as living with her own family in a nice house:

My heart feels sad when I run out of money to buy women's pads [sanitation pads]. I do not see future for myself. When I go to the English or Arabic class I think of my life. I don't work. I have no money. I have no future, no husband. I am stuck here. But my friends who work [as maids] have difficult life. They have to work for other people and feel humiliated. Their life is not better. I have no future. But I live with my family. I don't work for someone else. People will not look bad at me.

Nuriya's aunt, on the other hand, while appreciative of her niece's help with the housework and child care, feels that she, too, is carrying a big share of the family's burden by supporting Nuriya as well as remitting money to her extended family in Somalia. She has to juggle her obligations towards her extended family and those towards her husband and children. The aunt feels that her extended family often does not appreciate her support and financial sacrifices. Carrying out these responsibilities towards her extended family often creates tension between herself and her husband, who wants her to put their children as a priority. He continues to remind her that they have not been able to purchase an apartment in Cairo, unlike some émigré families, because she shares their income (from his job and her trade business) with her extended family. Thus while maintaining interdependent relations with family members within and across different nation-states is seen by Nuriya and her aunt as both a familial duty and a necessary livelihood strategy, both are conscious of the tensions and challenges that arise from competing interests and aspirations of different family members.

The practices of sharing residences and familial obligations between relatives in Cairo and in other countries also have their mixed consequences for refugee families. This is illustrated in the case of Abdullahi and Adan, two young male refugees in their early twenties. When they first arrived in Cairo from Somalia five years ago, they moved in with their married female cousin and her five children. Family members who were sending money to the brothers and the married cousin were involved in making these living arrangements for their relatives in Cairo so that they could consolidate family resources. The two young men's sister remitted them US\$100 a month from Holland, while the cousin's daughters send her and their younger siblings US\$200 from Saudi Arabia. The young men and their cousin shared rent and food expenses. Meanwhile, the cousin provided her younger relatives with food and house care. Financially, the living arrangement worked well for the young men and their relative. After paying their share of the rent, the brothers had some money left to spend on the Internet and in coffee shops. The married cousin also benefited from the financial assistance. Also, this living arrangement helped relatives in England and the United States to share other familial responsibilities such as sending remittance money to extended family in Somalia.

However, the brothers eventually differed with their older cousin on how to spend some of the money that was remitted to them. On the one hand, Abdullahi and Adan felt that paying LE 50 a month on renting a television was important to improve the quality of their daily life in which they had no jobs or opportunities for pursing formal education. On the other hand, the young men's cousin thought that they were squandering a considerable sum of money on a useless pastime instead of looking for work as tutors. Eventually, the disagreement resulted in the two brothers' moving out and rooming with six male friends. Yet, this conflict did not merely arise from the brothers' and their relative's different notions of how to make use of family resources. It was also related to a larger issue that had to do with the young men's frustrations with how family members in different nation-states (such as their sister in Holland, their maternal uncle and aunt in England, and other relatives in Somalia) were excluding them from decisions that impacted their lives because they did not contribute to the financial support of the family. For example, it was their 
relatives who decided who they should live with and how much money they needed. When Abdullahi and Adan moved out of their cousin's house, their sister was so unhappy that she decreased their remittance money to US\$50. Most of all, the relatives repeatedly turned down Abdullahi's request for financial assistance to pay for the costs of his clandestine travel arrangements to Italy via the Libyan borders.

In the course of the last two years Abdullahi met a Somali woman from Denmark on the Internet and they got engaged. His fiancée sent him US3,000, which he used to travel to Italy via Libya. After short imprisonment in Libya and a frightening sea journey in a small boat that took him from the Libyan to the Italian coast, Abdullahi managed to enter Italy. A few months later, he moved to Holland. He is currently applying for asylum in Holland where he is staying with his sister. His fiancée has also come to visit him. Despite their disagreements, Abdullahi still maintains close ties with his family. In addition to living with his sister in Holland for the time being, he e-mails his cousin in Cairo. Last year he sent money to both his brother and his cousin's family on the occasion of the holy month of Ramadan.

Again Abdullahi's and Adan's relations with their family illustrate both the significance and the challenges of being part of an interdependent transnational family. On the one hand, families become an important support system for sustenance and for sharing familial obligations. On the other hand, some family members feel that their own needs and dreams are undermined in decisions that are made by more powerful members about family resources and movement of relatives.

In short, examples of such practices of maintaining interdependent transnational families are numerous in the lives of both refugee and émigré families. For instance, a young divorced mother who works in England sent her child to Cairo to be taken care of by her elderly mother and young cousin who arrived from Somalia. The mother remits money to her family in Egypt and in Somalia including her cousin's mother. Another mother lives in Cairo with her children and her mentally ill twenty-year-old brother. While her husband, who lives in Saudi Arabia, does not send her any money since he married a second wife, her brother and older sister who also live in Saudi Arabia remit her a monthly sum of US $\$ 100$. The siblings feel obligated to support their sister, and are appreciative that she has undertaken the responsibility of taking care of their sick brother after the death of their parents. In other words, through practices of sharing particular living arrangements, resources, family obligations (e.g., child rearing and caring for the sick and the elderly) within and across nation-states Somalis in Cairo reproduce their ties with their transnational families and share resources with other family members.

Yet the practices of maintaining and making claims to transnational familial ties are not free from tensions and conflict among different family members as their needs, dreams, and desire for decision-making powers clash. It is often those family members who are most vulnerable because of their financial dependence and their unmarried status that feel these tensions. Many of the single men and women who depend on remittances from other family members for their livelihood feel marginalized in the decision-making processes that take place within their families. Furthermore, their unmarried status often contributes to their undermined status in the family since they are seen as inexperienced and lacking major family responsibilities such as child rearing. Ironically, most of these single individuals (particularly the women) do a lot of child care for family members with whom they live. Their pursuit of individual dreams such as travelling and starting their own families are seen by some family members as selfish acts that negatively impact the collective efforts of family members to remit money to those relatives who are most in need or to care for the sick and the elderly in the family.

It is often these marginalized family members who (more than others) see the Internet as a medium that enables them to fulfill several important needs. First, they use the Internet as a communication tool through which they negotiate their relations with different family members. Second, daily on-line chatting with fellow Somalis all over the world enables them to become part of a larger community of Somalis in which they feel they have more freedom and more voice, and in which their dreams seem more possible. In what follows, I examine the use of the Internet for family affairs and arrangement of marriages.

\section{Managing Family Affairs through the Internet}

Maintaining a transnational family is a necessity and a challenge for Somalis in Cairo. On the one hand, a transnational family life is a decision that more and more are opting for in order to maximize the well-being and strength of the family by pulling together the resources of different family members such as financial capital (e.g., income), legal status (permanent residence and citizenship), and social capital (e.g., education). On the other hand, the transnational lives of these families create tensions among individual members who face different problems and may have different goals. Decisions have to be made about the use of family resources and the wishes and goals of various members need to be prioritized in accordance with what is deemed as the good of the family. Understandably this results in differences and tensions among different family members. 
For most families in Cairo the Internet provides an inexpensive and highly effective audiovisual mechanism through which relatives in different parts of the world exchange their news, have discussions, resolve conflicts, and make or influence decisions about use of family resources. In Ard il Liwa and Nasr City neighbourhoods where most Somali refugees live, there are dozens of Internet cafes that sell affordable Internet time to local residents at a rate of LE 2 per hour. ${ }^{3}$ Since Somalis settled in these two neighbourhoods, these Internet cafes have been attracting a large number of Somali customers.

E-mail and on-line chatting become important means through which different family members have discussions, air disagreements, and make the case for their plans and dreams. The most popular use of on-line capabilities is to have interactive audio communications in which family members in Cairo, the West, and other regions of the world talk to one another back and forth about family affairs. While this technology is particularly attractive to Somalis who are semi-illiterate or find difficulty with using the keyboard, even literate and well-educated Somalis like using the audio services of the Internet in order to have more spontaneous communication. Therefore, communications of Somalis on the Internet are combinations of written and oral interactions.

Parents, children, siblings, and extended family members routinely send and receive e-mails and pictures to and from one another. Communications among families focus on the well-being of different family members, the rearing of children, the use of financial resources that are pooled from different members, and important family decisions such as marriages and relocation in different host societies. Family disagreements are also aired in these on-line communications. For example, some older children are scolded for rushing into marriages before attending to family obligations such as helping with the relocation of a parent, remitters are criticized for being late with sending remittance money, children who dropped out of school or failed to find employment are reprimanded, and husbands are chastised for taking second wives.

One of the fundamental links that tie many transnational Somali families is the monthly remittance money that is sent from the West or Gulf countries to relatives in Cairo and the homeland. Recipients of remittance money, particularly single men and women, often feel pressure from their family providers to show that they are spending money wisely and are involved in planning for their future and that of the family. The Internet has become an important mechanism through which these family members resolve their conflicts with family members, demonstrate their commitment to the family, and seek support from financially able family members.

Laila, a twenty-one-year old Somali single woman who lives with three female roommates, is a typical example of a young diasporic Somali who is part of a transnational family with whom she has strong financial and emotional ties as well as tensions because of their expectations and her individual dreams and plans for the future. Through regular e-mails, Laila maintains ties with her family: she shares her news and demonstrates her wise use of money and time in Cairo. Moreover, she participates in discussions about family resources and problems and negotiates for financial support for her future plans. Laila is supported by her maternal aunt who lives in Australia with her husband and children. Her aunt works as a housekeeper and remits US\$100 to Laila as well as another US\$100 to her elderly mother who lives with Laila's mother, father, and siblings in Somalia.

Since her arrival in Cairo from Somalia four years ago, Laila has been sending regular e-mails and often has interactive communications on the Internet simultaneously with her aunt and her parents and siblings. During her first six months in Cairo, Laila lived with her great-aunt and her children. Feeling that she would be more comfortable with young Somali women whom she has befriended, Laila decided to move out of her relative's house where she was not paying any rent but was doing a lot of housework. At first her aunt in Australia and her parents were not happy with her decision because of the financial costs and the lack of familial supervision in her new place. But Laila was adamant that living with her friends would give her time to study and find work.

Not wanting to alienate her family, Laila intensified her e-mail discussions with her relatives in Australia and Somalia. She regularly talked to them through the on-line chat services to explain and defend her decision. Shortly after moving in with her friends, she was able to enrol in free English classes for Somali refugees and obtain a part-time job as a babysitter for an American expatriate family. Her aunt and parents were reassured that she was being responsible and was able to pay her rent. Laila's e-mails to her family also had attached digital pictures of herself and her roommates in their apartment and in her English class to demonstrate to her family that she was leading a responsible and productive life in Egypt. Laila's aunt continues to remit US\$50 to her niece since the latter's job is not permanent.

While Laila has strong ties with her family and maintains regular communications with them, she feels that she is unable to pursue her individual plans and future because of her limited resources. This has created tensions between her and other family members. Like many young Somalis 
in Cairo, Laila feels that there is no future for her in Cairo. She wants to resettle in the West where she believes she can build a future for herself with the benefits of citizenship, education, and employment opportunities. For the first two years after her arrival in Cairo, she relentlessly tried to persuade her aunt and her brother who live in the West to finance smuggling her into Denmark where her brother lives. Laila's family, however, feels that Laila should focus on pursuing resettlement through the UNHCR office in Cairo despite the high rejection rate among Somali applicants at the time (in 2001 and 2002). The family's decision not to support Laila's individual efforts to resettle in the West is influenced by other family obligations, concerns, and desires.

For instance, Laila's older brother who is living in Denmark wants to focus on resettling his wife and son, who have been living in Ethiopia for the past few years. Also, Laila's parents believe that financing the travel of her younger sister from Somalia to Cairo is a higher family priority since she is being repeatedly harassed by armed militia men in the market where she sells tea and cigarettes. Laila's aunt and main provider has also become disillusioned and hesitant about helping a family member resettle in the West after her twenty-year-old son quit school and became estranged from the family. However, Laila feels that her family cannot appreciate the difficulties of living in Cairo where she has no long-term opportunities and has to depend on remittance money and the occasional income earned from housekeeping and babysitting. Although Laila has been recently recognized as a refugee by the UNHCR office in Cairo, she is not eligible for their educational grant because she is more than fifteen years old. She is still waiting to go through a series of resettlement interviews with the UNHCR.

\section{Love and Marriage on the Internet}

The Internet is the main mechanism through which Laila and her family maintain and negotiate their ties. Laila regularly goes to Internet cafés to send e-mails and chat on-line with her family. She has even obtained permission from her American employers to use the computer at their residence when their children are taking a nap. But for Laila and many other Somalis who feel trapped in Cairo, the Internet is not only a means of connecting with family. It is also a way of imagining and aspiring to different diasporic lives as these Somalis debate their past and present and discuss their future with fellow Somalis living all over the world. Seeking marriage partners is one popular way through which many single Somalis plan for a different future.

For many who live in Cairo, the most desirable partners are those living in the West because marriages with such partners provide opportunities for resettlement and a better future. One of Laila's roommates has "met" a Somali man living in Holland on the Internet, and they are planning to get married once he obtains his Dutch passport in few months. Marriage seekers in the West, on the other hand, are attracted to potential partners in the Middle East for two main reasons. Some believe that Somali spouses from the Middle East are more family-oriented and less individualistic than those who have lived in the West for a long time. Also some of the single people in the West work long hours and lack the social networks that can help them find suitable partners in their immediate environments, and thus they seek them instead on the Internet or in wedding videotapes sent by friends and family members from Cairo.

Young men and women who are seeking romantic relationships and potential marriage partners often use the following strategies: They log in to different chat rooms in which they engage in discussions with different male and female interlocutors about different topics. The topics vary but the most common ones focus on relationships between Somali men and women, family relationships, clan relations, and life for Somalis in different nation-states. Then if the person finds a potential partner among the participants in the discussion, he or she communicates with them separately. While by far this is the most common strategy used by many in seeking marriage partners, some Somalis (men and women) also post personal marriage advertisements in the matrimony section in Somalinet.com. There are also people who are set up by family or mutual friends and then establish a pre-engagement on-line relationship in order to get to know one another.

Although such matches may appear to be convenience marriages, it is simplistic to reduce them to relationships that are solely motivated by material interests.

While many young men and women seeking partners recognize that suitors living in the West provide them with much needed opportunities for a secure and better future, marriage seekers from Cairo stress the importance of many other requirements in potential spouses, which also reflect their opinions on pertinent issues to Somalis in Diaspora. For example, there are those who are interested in finding spouses who belong to the same clan. This is mostly true of those who belong to minority clans. Some marriage seekers are also interested in partners who are religious. Women are particularly keen on finding Somali men who take their family responsibilities seriously and do not use religion as a justification to take more than one wife. In what follows, I will give ethnographic examples of romantic and marriage relationships that have been established through the Internet. These examples demonstrate the challenges of single 
men and women because of their transnational family lives in which they lack decision-making power, more access to family resources, and higher status within the family. Thus on-line courting, through which romantic relationships are established with desirable marriage partners, becomes a way for these young men and women to dream and (sometimes) realize a life in which they have financial independence and become more valued members of their families.

Abdi, a twenty-eight-year-old Rahanweyn man, was seeking to marry a religious Rahanweyn woman who lived and had legal status in Australia where his parents and younger sisters live. On the Internet, he met Rahma, a twenty-six-year-old Rahanweyn divorcee with two children who lived in Melbourne. Abdi feels that he has fewer doubts than he first did now that he has been having an elevenmonth on-line relationship with his fiancée. He is also encouraged by the reports of his parents and younger siblings who visited Rahma in Melbourne. Although his parents would have liked him not to marry a divorcee, they reported to him that they felt better about the match because Rahma is from their clan and she made a favourable impression on them during the visit. Abdi admits that he sometimes worries that his future wife may have too much power in their marriage because of the legal security and the rights she enjoys as an Australian national. He says it bothers him a little bit when his friends tease him that Somali wives in the West have too much power. One of his friends told him that "if he does not behave, Rahma will call the police to take him away." However Abdi reassures himself that Rahma is "religious and humble as most Rahanweyn wives are." Abdi is also hopeful that his college degree and his good English skills will help him get a job quickly so that he will not feel dependent on his future wife.

However, not all Internet couples who are compatible manage to establish successful marriage relationships. Some relationships fail because of the lengthy period of paperwork that is necessary before the couple can be united in the West. Mahmoud and Khadra met on-line. She lives in Cairo while he lives in England. They are compatible in many ways and had a four-year-long relationship. They are both in their mid-twenties. Both are interested in pursuing their education. Khadra has been working hard to get a high school degree at an Al-Azhar school for foreign adult learners and has been taking English courses. Mahmoud works part-time and goes to college in England. Mahmoud's parents, who are working in Dubai, blessed the relationship and even sent an invitation visa to Khadra so that she could visit them. During her one-month visit to Dubai, Khadra and Mahmoud got married. When she returned to Cairo, they continued communicating via e-mail and by tele- phone. Mahmoud started the paperwork with the British Immigration Department for his new wife's immigration. Meanwhile, he remitted her US\$100 every month. However, the paperwork dragged on for four years during which Mahmoud met another Somali woman in London. He wrote to Khadra and told her that he decided to marry this woman. Since he could not have two legal wives in England, he gave Khadra the option of staying in the marriage if she agreed to continue living in Cairo where he would visit her once or twice a year. Khadra opted for divorce. She said, "I want a real marriage not a man who sends me money and visits me once in a while." She felt bitter that she wasted four years of her life in this relationship.

In addition to using the Internet as a way of negotiating family tensions and seeking marriage partners, young men and women also use it as a window to a larger Somali world in which they can feel less dependent and less trapped. Ilham, a twenty year old, and her two female roommates go to the Internet cafés almost every day. Ilham and her sister live on US\$50 that is remitted to them by a brother living in Seattle. Their parents and the rest of their siblings in Somalia also depend on remittances sent by other siblings in Saudi Arabia. Ilham and her sister are often criticized by their siblings for not being able to live on US\$50, which the girls believe is insufficient. Ilham's sister recently got a job as a nanny for a Somali family from England in order to supplement their monthly income. The girls are not sure whether to tell their relatives about their new source of income.

Both Ilham and her sister explain that they feel trapped and helpless in Cairo without possibilities of pursuing education or planning for a future. That is why going on-line is a way for Ilham to become part of a larger and more open diasporic world. Ilham says that she enjoys learning about the lives of Somalis who live in different parts of the world. She reads posted pieces written by the visitors of Somalinet.com and Paltalk.com about different issues such as marriage, rearing children, work, and education opportunities in different host societies, and the lives of diasporic Somalis in various nation-states. She enjoys frequenting chat rooms where people talk about a wide range of issues such as clan divisions, the ongoing civil war, the latest in Somali music, gender relations, etc. Her hours on the Internet enable Ilham to inhabit a larger world of diasporic Somalis where different kinds of lives are possible. She says she is not necessarily focused on meeting a desirable marriage partner on the Internet, but rather uses the Internet to get more information about life in the West where she wants to resettle and to learn more about diasporic Somalis. She says: 
It (the Internet) is a big world of Somalis. There are bad things but a lot of good things. There are some people who only get on-line for the sexual things or to insult other clans. I like to listen to different Somalis. They talk about education, work, the war, religion, marriage. I can now understand how Somalis in the West live and think. Some are educated and good. Others are bad and still think of clanism. Sometimes I learn things about Somalis in Cairo. I saw a picture of a woman who was very sick and needed help for her heart operation. I did not know that she lived in Ard il Liwa like me.

Ilham and many like her use the Internet to escape their feelings of frustration with their hard and limited life in Cairo and their lack of power and autonomy within their own families. The Internet becomes for them an accessible and effective means through which they imagine and experience a more open diasporic life in which they can connect with others who have made it to the West, and learn about the opportunities and the problems of Somalis in different nation-states.

In addition to learning about different aspects of diasporic lives that are possible for Somalis living elsewhere, some of these young people use this virtual space to assume different identities. Some males and females lie about their diasporic experiences, their legal status, and educational skills when they engage in on-line chatting with other potential romantic partners. Understandably the most commonly used trick is to claim falsely that one is living or has lived in the West and has a citizenship status there. Men and women explain that these kinds of lies make them more desirable marriage partners. Some of those who lie about their diasporic experiences admit that these kinds of lies cannot be maintained and argue that they are motivated by a desire to experience a romantic relationship in which they feel that they are desirable partners even if such relationships do not last. Others say that they hope that by the time they have to reveal the truth to their on-line romantic partners, they will have formed a relationship of love that will make it easy for their partners to forgive them. But there is an interesting group of people who say that they pretend to be what they are not as a way of imagining lives that they would like to have but cannot at the moment. For these people, it is not so much lasting romantic relationships that they are seeking but imagining different kinds of diasporic lives.

Thus, the Internet provides a mechanism through which individuals can discuss important family issues and resolve conflicts. It also creates opportunities for establishing romantic relationships with potential marriage partners in the West. This is particularly significant for young men and women who cannot get married in Cairo due to their financial and legal conditions. ${ }^{4}$ The Internet also creates a more inclusive world for individuals who feel marginalized within their families and their current diasporic environment.

It has been well-documented that many diasporas use the Internet in communicating and maintaining ties with families and communities across the globe. ${ }^{5}$ In their ethnography of Internet use among Trinidadians in Diaspora and the homeland, Miller and Slater show that their informants succeed-through the Internet-in creating a transnational space that is distinctly Trinidadian. ${ }^{6}$ Extended families reconnect through e-mails and in on-line chats. Romantic relationships with other Trinidadians are pursued. Moreover, the religious beliefs and rituals of particular Trinidadian religious groups such as followers of the Apostolic Church and the Catholic Church are reaffirmed on-line. That is, the authors show how Trinidadians from different social classes and ethnic groups use a global resource such as the Internet to construct a Trinidadian identity to be shared with fellow compatriots.

Kadende-Kaiser and Kaiser also argue that Burundians in different nation-states make use of Burundinet, an Internet Web site established by diasporic Burundians, to create a transnational Burundi identity which Burundians, of different ethnic groups, can make claims to. ${ }^{7}$ The authors explain that diasporic Burundians who engage in on-line debates about this issue believe that the reformulation of such a collective Burundi identity is more viable on a transnational space in which people can have distance from divisive ethnic identities.

Somalis' uses of the Internet are similar in many ways to those of other diasporic communities. Through the Internet, Somalis in Cairo create a space in which they and their transnational families and fellow Somalis elsewhere in Diaspora become part of the same world. Inhabiting this common world enables Somalis to maintain family ties, negotiate tensions, impact family decisions, pursue new ties through marriage, and participate in the construction of a transnational community of Somalis. Moreover, the oral communications that take place between family members and among fellow Somalis in the chat rooms make this virtual Somali world more real.

\section{Family Videotapes: Managing Family Affairs and Starting New Families}

In addition to the Internet, videotapes are important means through which Somalis in Cairo interconnect with their families. Videotapes are being used by more Somalis to send and receive news from other family members, to share information about life in different nation-states in order to make informed decisions about relocation, and to arrange new marriages. 
Videotapes of wedding parties are one example of how this technology is used to fulfill some of the above-mentioned purposes. There are two kinds of wedding videotapes. There are tapes that record wedding parties held by family members living in Cairo for couples who got married and are living in the West. To save on expensive costs of wedding parties, the newlyweds send money to their families in Cairo to have a wedding party for them. The families hold a party in Cairo and videotape it. The videotape is then sent to the couple who watch it with other friends and family members. Couples who finance their transnational wedding parties point out this practice not only appeases their relatives in Cairo but also demonstrates to their new spouses their strong ties with their families, a quality that is respected and valued by most Somalis. Such wedding parties are attended by many single women who hope to attract the interest of potential suitors among the friends of the couples. Many single men in the West also watch such videotapes to look for potential wives.

Some newlyweds and their families in the West also send videotapes of their wedding parties which were held in their host societies. These tapes are viewed by their family members in Cairo along with their friends and neighbours who might be looking for potential partners for themselves or their single relatives. In fact, a sizable number of marriages have been arranged between men and women living in Cairo and in the West by family members and friends who have shared videotapes of weddings in Egypt and the West.

In addition to recording wedding parties, families videotape different aspects of their daily lives to share their news with relatives living elsewhere, and in some cases to provide these relatives with information about life in a host society to which the relatives want to move. For example, some of the families in the West who want to move to Cairo to pursue better education opportunities for their children or to improve their socio-economic conditions send one of the parents or older children to Cairo on a fact-finding mission. The visiting relative videotapes his or her visit in Cairo, which includes encounters and conversations with different relatives, friends, clan members, and fellow Somalis who offer their perspectives on living in Cairo. The videotape also features different neighbourhoods where Somalis live and the area where the family will probably live. Such tapes are viewed by the families back in the West along with friends and other families who are interested in moving to Cairo.

For example, before Mohamed, a forty-year-old married man who works for a Somali hawala (an office that provides money-transfer services) in Sweden, moved his wife and children to Cairo, he visited the city in late 2002 to collect information from his relatives and friends. Using a video camera, Mohamed spent three weeks in the city recording visits with relatives and Somalis living in Ard il Liwa and Nasr City. He recorded hours of conversations with his relatives and some of the Somalis he met in Cairo in which they discussed the benefits and challenges of living in the city. The tape showed people's homes, neighbourhoods, their friends, and daily aspects of their lives such as men gathering in coffee shops, women buying groceries, other women selling homemade food to Somali families, and children receiving tutorials in the Quran. Some of Mohamed's family members who live in Cairo took advantage of the opportunity and videotaped messages and requests to other family members living in Sweden and other European countries. I was informed by Mohamed's wife, who moved to Cairo with her children six months later, that the tape was viewed by herself and a wide circle of relatives on both her side and Mohamed's side of the family as well as friends and neighbours living in Sweden, Denmark, and the US. Mohamed's wife pointed out that the video was useful in giving her a vivid picture of life in Cairo. Videotapes such Mohamed's are very common and are sometimes made by relatives who are already living in Cairo and then sent to family members in the West who are considering moving to Egypt.

Another kind of family videotape that is shared by family members records the daily lives of new arrivals in the West. These tapes show the new apartments, neighbourhoods, workplaces, and schools of relatives who have settled in various towns in North America and Europe. The tapes are sent to family members in Cairo so that they can get a better idea of the lives of their families in Western countries. Such tapes are important means for family members in the West to convey to relatives in Cairo their success stories or to highlight their numerous responsibilities and share their concerns about the future of the children they are raising. Thus the tapes become a tool through which the senders attempt to convey particular messages to the recipients and influence family decisions about remittance money and movement of family members from one host society to the other. The recipients of these videotapes, on the other hand, make use of them not only as family communications but also as materials which they share with friends and neighbours to show off their family-based resources and to debate the benefits and challenges of living in the West and in Cairo.

\section{Conclusion}

I have argued that the living arrangements of most families in Cairo are planned practices through which family members in Egypt and elsewhere share resources (e.g., money, housing, benefits of legal status) and obligations (e.g., child 
rearing and caring for elderly and sick family members). While sharing resources and obligations across nation-states creates and reproduces interdependent transnational families, family members have uneven access to resources and decision-making power. Financially dependent single men and women are those who feel most marginalized within their families. Thus such individuals have to negotiate conflicts and tensions arising from the same transnational practices that enable them and families to secure livelihood and share resources.

Transnational family ties are not only reproduced through the sharing of resources and obligations but also through sustained communication among family members. The Internet becomes an effective audiovisual communication tool through which families exchange news and debate family affairs. Unlike long-distance telephone calls, the Internet is an inexpensive daily tool of communication that is available to Somalis in neighbourhood Internet cafés. For single men and women, in particular, the Internet becomes useful in several ways. First, it enables them to engage in family debates to resolve disagreements with other family members, and to negotiate family support for individual plans and dreams. Second, these Somalis pursue on-line romantic relationships with desirable marriage partners (who live in the West). In fact, some of them succeed in entering into such marriages. While these online marriage arrangements cannot be reduced to mere relationships of convenience, they have their various limitations and challenges. Third, the Internet enables these young men and women to enter a space where they can imagine alternative diasporic lives that are more desirable than the ones they live. Through on-line discussions with fellow Somalis living in the West and elsewhere, they learn about how other diasporic Somalis live, what opportunities and challenges they face in different nation-states, and the common concerns of diasporic Somali communities in different parts of the world.

Thus the Internet is a world in which those refugees who feel marginalized within their families and in their current diasporic environment become part of a freer and more open world. It is interesting that this world remains one that is very much Somali, albeit heterogeneous. In other words, because the diasporic trajectories of these single men and women are shaped by those of their families and local communities, even when they seek (on-line) a way out of the limitations of their world, they do so within a space that does not escape the identity discourses that shape their ethnic diasporic world.

Videotapes are also widely used and effective in the management of family affairs across nation-states. Videotapes of family events such as weddings and daily lives in new host societies are used by family members living in Cairo and elsewhere (particularly the West) to share family news, to arrange marriages for single relatives and friends, and to gather information in order to make decisions.

Braziel and Mannur argue for an important distinction between transnationalism and diasporas. They define transnationalism as the "flow of people, goods, ideas, and capital across national territories in a way that undermines nationality and nationalism as discrete categories of identification, economic organization, and political constitution." ${ }^{8}$ Diaspora, on the other hand, according to them refers to the actual experiences of movement of people. That is, Diaspora is a "human phenomenon," unlike the impersonal larger processes of transnationalism. I think this kind of distinction between transnationalism and diasporas overlooks the transnational practices that are the essence of most contemporary diasporic lives. In fact, a typical feature of diasporic lives is extensive and regular transnational networking and ties that often become necessary not only for the financial sustenance but also for the social and cultural survival of families and communities. Therefore, I think transnationalism is a relevant concept in the study of diasporic communities because it allows us to highlight the conscious and planned practices of family members in different nation-states to secure livelihood, maximize legal capital (for example by pursuing citizenship in Western countries through physical separation from other family members), and maintain social capital (e.g., by raising "committed" and "dependable" children).

In conclusion, Somali refugees and Somali Western nationals who live in Cairo are diasporic individuals who make use of transnational practices to secure livelihood for their families, to acquire social capital within their communities, and to resist marginalization by host societies and some of their ethnic communities. Yet, this way of being and living in which individuals and families partake as they are physically separated in different nation-states has its uneven consequences and challenges for different Somalis depending on their legal statuses, education, gender, and identity claims.

\section{Notes}

1. See 2004 Global Refugee Trends: Statistical Overview of Populations of Refugees, Asylum Seekers, Internally Displaced Persons, Stateless Persons, and Other Persons of Concern to UNHCR (Geneva: UNHCR, 2005).

2. For in-depth analysis of the diasporic lives of Somali refugees and émigrés in Cairo see Mulki Al-Sharmani, "Refugees and Citizens: The Somali Diaspora in Cairo" (doctoral thesis, Johns Hopkins University, Baltimore, MD, 2004).

3. One US dollar is 5.8 Egyptian pounds. 
4. Those who get married in Cairo live separately and hide their marriages from their families.

5. See M. Grang, P. Grang, and J. May, eds., Virtual Geographies (London: Routledge, 1999); C. Ho, Salt-Water Trinis: AfroTrinidadian Immigrant Networks and Non-Assimilation in Los Angeles (New York: AMS Press, 1991); A. Markham, Life Online (New York: Sage, 1998); A. Rai, "India Online: Electronic Bulletin Boards and the Construction of a Diasporic Hindu Identity," Diaspora 4 (1995): 31-57.

6. See Daniel Miller and Don Slater, The Internet: An Ethnographic Approach (Oxford and New York: Berg, 2000).

7. See Rose Kadende-Kaiser and Paul Kaiser, "Identity, Citizenship, and Transnationalism: Ismailis in Tanzania and Burundians in the Diaspora," Africa Today 45, no. 4 (1998): 461-479.

8. Jan Evans Braziel and Anita Mannur, eds., Theorizing Diaspora (Malden, MA: Blackwell Publishing, 2003), 8.
Mulki Al-Sharmani is a research assistant professor at Social Research Center, the American University in Cairo. She received her doctorate in cultural anthropology from the Johns Hopkins University, Baltimore, MD, in 2004. Her current research interests include the economic activities and community activism of Somali refugee women and poor Egyptian women in Egypt, the lived experiences of citizenship and non-citizenship among refugees and poor Egyptians in Cairo, and the policies and practices of child protection in Egypt. 